\title{
Correlates of Tribal Women's Empowerment in Tripura
}

\author{
Keshab Jamatia ${ }^{1}$, M. N. Ray ${ }^{1}$, Sadananda Payeng $^{1}$, Leema Bora ${ }^{1}$, \\ Monosri Johari ${ }^{1 *}$ and Deepjyoti Roy ${ }^{2}$ \\ ${ }^{1}$ Department of Extension Education, \\ ${ }^{2}$ Department of Livestock Production and Management, College of Veterinary \\ Science, AAU, Khanapara, Guwahati-22, India \\ *Corresponding author
}

Keywords

Women,

Respondent, Tribal,

Empowerment,

Livestock,

Enterprise

Article Info

Accepted:

17 January 2021

Available Online:

10 February 2021
A study was conducted with a view to assess the overall empowerment level of tribal women in Tripura. Two major tribes viz. Jamatia and DebBarma predominantly inhabiting the Gomati and Sepahijala district were purposively selected. Four villages from each of the two districts were selected and from each village a total of 25 respondents were selected to make the sample size 200. Empowerment of tribal women was measured by constructing a women's empowerment index given by Mahmud et al., with minor modifications. The reliability of the instrument was tested by test-retest method, while content validation was applied for validity. The findings revealed that majority of the respondents in both the tribes had medium empowerment level. But in correlation analysis they exhibited a substantial departure from each other. In DebBarma tribe five variables annual income from sources other than livestock, attitude towards improved livestock farming, liking of information source, entrepreneurship behavior and social participation showed significant positive correlation with empowerment level. However in multiple regression only two variables liking of information sources and entrepreneurship behavior showed significant contributory effect on empowerment level. In Jamatia tribe as many as 8 variables viz. mass media exposure, extension contact, annual income from livestock, total annual income from all sources,, annual income from sources other than livestock, entrepreneurship behavior, liking of information sources and attitude towards improved livestock farming showed significant positive correlation with empowerment level. However in multiple regression only three variables herd size, entrepreneurship behavior and participation in livestock activities displayed a significant contributory effect on the level of overall empowerment. 


\section{Introduction}

Empowerment may be defined as the multidimensional process of making the women realize their identity, rights, position and status in various fields of our society. Different studies and surveys have revealed that tribal women are less empowered in almost all aspects of their life. Tripura is not an exception to this. The tribal women in Tripura are acquainted with livestock enterprises since time immemorial. They have been rearing livestock and poultry from generation to generation as livestock produce and product meet their animal protein requirement and also play a pivotal role in their socio-cultural life. Of late, they have started adopting scientific know-how in their livestock production practices to augment their income. Therefore, it is a very pertinent to investigate as to what extent livestock enterprises have contributed in empowering the tribal women in Tripura. Moreover this empowerment may not be expected to happen uniformly in the tribal society of Tripura. It is logical to surmise that some sort of variation in empowerment level may happen in accordance with their personal, economic and social and psychological traits of the respondents. Against such backdrop the study was undertaken with the following two objectives-

To find out the level of empowerment of tribal women in Tripura through livestock enterprises.

To find out the relationship of perceived empowerment level of the tribal women of Tripura with their socio-economic and psychological traits.

\section{Materials and Methods}

A tribal woman rearing at least 2 pigs or 2 goats or 10 poultry or 1 cattle was considered eligible as respondent of the present study. Out of the 19 major tribes in Tripura two tribes viz. DebBarma and Jamatia were purposively selected for this study. The two contiguous districts of Tripura viz. Sepahijala and Gomati were also purposively selected as the area of the study. The Jamatia tribe is predominant in Gomati whereas DebBarma is predominant in Sepahijala district. A total of 100 respondents were selected by snowball sampling method from each of the two districts to make the sample size 200 .

In this study women's empowerment was measured by constructing women's empowerment index using the dimensions in line with Mahmud et al., (2012) with minor modifications. The dimensions are- economic empowerment, socio-cultural empowerment, politico-legal empowerment, decision making empowerment and psychological empowerment. Each dimension further contains various indicators which have been spotted according to Islam et al., (2012). Each indicator further contains several questions pertaining to practical situation. Responses were received on the basis of four-point Likert scale $(1=$ not at all, $2=$ to some extent, $3=$ to an average extent, $4=$ to a great extent). For each respondent score of all individual items were summed up to get the total scores. Thus the respondents were categorized as low, medium and high in the five dimensions. Pre-testing was conducted on 20 non-sample respondents to estimate the reliability of the scale. On the other hand content validity was ascertained to test the validity of the scale.

\section{Result and Discussion}

\section{Empowerment level}

Table 1 revealed that there were five components of women empowerment viz. economic, socio-cultural, politico-legal, decision-making and psychological. The 
scores of these components for each respondent were summed up which yielded the overall empowerment level. As indicated in table 1 it showed that majority of the respondents of DebBarma perceived medium (78.00 per cent) level of overall empowerment followed by those with low (13.00 per cent) and high (9.00 per cent) level. The mean and standard deviation were 248.59 and 15.933 respectively.

On the other hand, in Jamatia tribe majority of the respondents perceived medium (83.00 per cent) level of overall empowerment followed by those with low (12.00 per cent) and high (5.00 per cent) level. The mean and standard deviation were 251.01 and 17.90 respectively.

In pooled data it was observed that majority of the respondents perceived medium (80.50 per cent) level of overall empowerment followed by those with low (12.50 per cent) and high (7.00 per cent) level. The pooled mean and standard deviation were 249.8 and 16.946 respectively. The ' $t$ ' value (1.0009) was found to be non-significant.

This might be due to the fact that they follow same tradition and culture and there is not much different between these two tribes, even though they are geographically apart, they show similar trend of empowerment. There is no distinct difference in their overall empowerment through livestock enterprises.

This finding was supported by several authors like Kochar (2012) who in his study on role of dairy cooperatives in empowerment of rural women of Ludhiana district found that there was improvement in economic resources of the family, women's own development, decision making capacity regarding education and marriage of children and participation in social activities. Patel et al., (2016) also reported that women constitute about 69 per cent of workforce engaged in livestock sector and women also utilized the raw material provided by animal such as wool, skins, and bones to make clothes, or as fuel for home consumption and for sale and thereby processing of these materials acted as an important source of additional employment and income for poor rural women. Anonymous (2012-17) also revealed that there was a need to correct gender bias in livestock sector, veterinary education, research and service delivery systems as to enhance the effectiveness of women-orient livestock development programs. Anonymous (201217) also revealed that sustainable development of the livestock sector would lead to more inclusive development and empowerment of women. Saikia, P. (2017) also in his study on 120 tribal women in Lakhimpur district of Assam found that majority (60.00 per cent) of the respondents got support from husband followed by parents (31.67 per cent). Kalai and Devarani (2018) also in their study in Charilam block of Sepahijala District of Tripura on 120 respondents of which 60 numbers were women (30 tribal and 30 nontribal) and 60 numbers were man (30 tribal and 30 non-tribal) reported that percentage of tribal women (70.00 per cent) were found more empowered than non-tribal women (50.00 per cent). Torkelsson and Tassew (2008) also in their study on quantifying women 's and men 's rural resource portfolios-empirical evidence from Western Shoa in Ethiopia revealed that the value of livestock in the female-headed households was considerably greater than that of livestock in the male-headed households. Further reported that the care of livestock was traditionally being regarded as a female activity. Yasmin and Ikemoto (2015) also in their study fifty rural women in the Mymen singh District of Bangladesh found that rural women from Salakandi village were able to increase their confidence and decision making power with regard to their household and personal care and experienced raised self- 
esteem, expansion of their social circles, and ultimately enhanced empowerment through the breakdown of traditional socio-cultural norms.

Hassan (2000) also in their case study of BRAC on assessing the poverty and vulnerability impact of Micro-Credit in Bangladesh reported that membership in micro-credit programmes reduces vulnerability by creating various channels like income and consumption smoothing, building assets, providing emergency assistance during natural disasters, and contributing to women's socio-economic empowerment. Islam (2012) also reported from his study that 86.00 per cent of rural women participated in awareness programmes on microfinance, skill development (75.00 per cent), SHG (72.00 per cent) and marketing linkages (70.00 per cent) found increased in their income.

Islam (2012) also revealed that majority of rural women had increased their mobility, decision making, confidence, self-respect, knowledge, awareness about social issues and women's reservation in job after availing microfinance. Duguma et al., (2011) also in their study on 54 respondents in Jimma town, Oromia Region, Ethiopia revealed that men decide selling of animals (37.00 per cent) and milk (31.50 per cent), while women decide how much of the milk will be kept for household consumption (61.10 per cent). Chauhan (2011) also found in his study that management in animal husbandry was completely dominated by women's selfdecision.

Debbarman (2017) also reported that majority of the decision making relating to livestock management were taken by men and majority of activities where men were seen as decision maker were like purchase of animal (64.75 per cent), choice of animals (80.25 per cent), cultivation of fodder (74.75 per cent), breeding/ fattening of pig (93.25 per cent), infrastructure improvement (83.00 per cent), purchasing of equipment (47.00 per cent).

Whereas it was observed that women shared responsibilities with their male counterpart in majority in activities like selection of animals to be reared (61.00 per cent), number of animals to be kept (56.00 per cent), type of feed to be given to animals (78.00 per cent), sale of products ( 74.50 per cent), quantity of piglet to be sold (49.50 per cent) and utilization of income from pig (53.25 per cent).

Further he revealed that equal share of decision in activities like sale of animal (50.50 per cent), health care and treatment of pig (58.75 per cent) and expenditure and procurement of loans (48.00 per cent) were observed. Malik et al., (2015) also reported that rural women could give only suggestions to their spouse in decision making regarding animals' purchase and sale, insurance, loans, participation in support programmes (like trainings) and not taking decisions independently.

Further, they found that only 1.67 per cent of women were found beneficiaries of training in last 5 years. Further, they also reported that around 5.00 per cent women visited the hospital for treatment as compared to 95.00 per cent men and only 15.00 per cent women were beneficiaries of loan as compared to 85.00 per cent men.

Talukdar (2012) also revealed that majority 76.00 per cent occupied medium category of attainment of empowerment followed by 14.00 per cent in high and 10.00 per cent in low category. Jyothi (1998) also revealed that majority of women belonged to medium level of empowerment (58.00 per cent), while few women (8.00 per cent) belonged to high level of empowerment; remaining (54.00 per cent) 
women had low level of empowerment. Relationship of Women empowerment with Socio-economic and psychological traitsCorrelation and regression analyses were conducted to assess the relationship of empowerment level with socio-economic and psychological traits. Table 2 is presented below to show the correlation coefficient whereas Table 3 depicts the multiple regression coefficient.

It was evident from Table 2 that out of 16 variables only four variables viz. annual income from sources other than livestock and poultry $\left(\mathrm{r}=0.286^{* *}, \mathrm{P}<0.01\right)$, attitude towards improved livestock farming $\left(\mathrm{r}=0.385^{* *}\right.$, $\mathrm{P}<0.01)$, liking of information sources $\left(\mathrm{r}=0.363^{* *}, \quad \mathrm{P}<0.01\right), \quad$ entrepreneurship behaviour $\left(\mathrm{r}=0.325^{* *}, \mathrm{P}<0.01\right)$ showed highly significant and positive relationship with perceived empowerment level in DebBarma tribe whereas social participation $\left(\mathrm{r}=0.218^{*}\right.$, $\mathrm{P}<0.05)$, exhibited significant and positive correlation with perceived empowerment..

In Jamatia tribe out of the 16 variables only eight viz. mass media exposure $\left(\mathrm{r}=0.310^{*} *\right.$, $\mathrm{P}<0.01)$ extension contact $\quad(\mathrm{r}=0.363 * *$, $\mathrm{P}<0.01$ ), annual income from livestock and poultry $\left(\mathrm{r}=0.274^{* *}, \mathrm{P}<0.01\right)$, annual income from sources other than livestock and poultry $\left(\mathrm{r}=0.249^{* *}, \mathrm{P}<0.01\right)$, total annual income from all sources $\left(\mathrm{r}=0.271^{* *}, \quad \mathrm{P}<0.01\right)$, attitude towards improved livestock farming $(\mathrm{r}=0.211 * *, \mathrm{P}<0.01)$, liking of information sources $(\mathrm{r}=0.231 * *, \mathrm{P}<0.01)$, entrepreneurship behaviour $(\mathrm{r}=0.782 * *, \mathrm{P}<0.01)$ had significant positive relationship with empowerment level as was evident from Table 2.

In the pooled sample perceived empowerment level had positive but significant relationship with social participation $\left(0.318^{* *}, \mathrm{P}<0.01\right)$, annual family income from livestock and poultry $\left(0.306^{* *}, \mathrm{P}<0.01\right)$, attitude towards improved livestock farming (0.368**,
$\mathrm{P}<0.01)$, liking of information sources $\left(0.415^{* *}, \quad \mathrm{P}<0.01\right)$ and entrepreneurship behaviour $\left(0.420^{* *}, \mathrm{P}<0.01\right)$. The significant relationship of annual family income of the respondents of DebBarma tribe from sources other than livestock was indicative of the fact that higher income from sources other than livestock was delivering them higher empowerment level. The other sources of income were rubber plantation, pisci-culture, horticulture, etc. wherefrom they derived substantial profits as well as economic empowerment.

On the other hand, the significant positive relationship of attitude toward improved livestock farming implied that favourable attitude towards improved livestock farming led to higher empowerment level.

It can easily be surmised that this positive attitude formation towards improved livestock farming occurs due to multiple factors which may include the health outcome gained from different livestock produce and product, meeting up of the children's educational expenditures from income earned through livestock enterprises and ease in performing socio-cultural ceremonies.

The positive and highly significant correlation of liking of information sources with empowerment level pointed to the fact that the respondents gathered information related to social, political, legal and economic issues and the utilization of such information in the real life might have enhance their empowerment level.

The significant relationship exhibited between entrepreneurship behaviour and empowerment level implied that when the respondents were ready to take up some venturesome enterprises, willing to take risk and possessed coordinating and planning ability, they derived higher empowerment level. 
Table.1 Distribution of the respondents on the basis of their overall perceived empowerment

\begin{tabular}{|c|c|c|c|}
\hline \multirow{2}{*}{ Category } & DebBarma & Jamatia & Pooled \\
\cline { 2 - 4 } & Frequency & Frequency & Frequency \\
\hline Low (<232.853) & $13(13.00)$ & $12(12.00)$ & $25(12.50)$ \\
\hline Medium (232.853-266.746) & $78(78.00)$ & $83(83.00)$ & $161(80.50)$ \\
\hline High (>266.746) & $9(9.00)$ & $5(5.00)$ & $14(7.00)$ \\
\hline Mean & 248.59 & 251.01 & 249.8 \\
\hline Standard Deviation & 15.933 & 17.900 & 16.946 \\
\hline 't' value & & $1.000^{\mathrm{NS}}$ & \\
\hline Range & $212-296$ & $191-318$ & $191-318$ \\
\hline
\end{tabular}

Table.2 Correlation coefficient of women empowerment with their socio-economic and psychological traits

\begin{tabular}{|c|c|c|c|c|}
\hline \multirow[t]{2}{*}{ Sl. No. } & \multirow[t]{2}{*}{ Independent variables } & \multicolumn{3}{|c|}{ 'r' value } \\
\hline & & DebBarma & Jamatia & Pooled \\
\hline 1 & Age & $0.085^{\mathrm{NS}}$ & $0.010^{\mathrm{NS}}$ & $0.102^{\mathrm{NS}}$ \\
\hline 2 & Family size & $0.089^{\mathrm{NS}}$ & $-0.108^{\mathrm{NS}}$ & $0.069^{\mathrm{NS}}$ \\
\hline 3 & Educational level & $0.139^{\mathrm{NS}}$ & $0.061^{\mathrm{NS}}$ & $0.001^{\mathrm{NS}}$ \\
\hline 4 & Social participation & $0.218 *$ & $0.094^{\mathrm{NS}}$ & $0.318 * *$ \\
\hline 5 & Occupation & $-0.039^{\mathrm{NS}}$ & $0.014^{\mathrm{NS}}$ & $-0.044^{\mathrm{NS}}$ \\
\hline 6 & $\begin{array}{l}\text { Experience(yr.) in livestock } \\
\text { farming }\end{array}$ & $0.118^{\mathrm{NS}}$ & $0.057^{\mathrm{NS}}$ & $0.123^{\mathrm{NS}}$ \\
\hline 7 & Herd size & $0.132^{\mathrm{NS}}$ & $0.146^{\mathrm{NS}}$ & $0.151^{\mathrm{NS}}$ \\
\hline 8 & Land size(acre) & $0.136^{\mathrm{NS}}$ & $0.113^{\mathrm{NS}}$ & $0.113^{\mathrm{NS}}$ \\
\hline 9 & Mass media exposure & $0.161^{\mathrm{NS}}$ & $0.310 * *$ & $0.060^{\mathrm{NS}}$ \\
\hline 10 & Extension contact & $0.004^{\mathrm{NS}}$ & $0.363 * *$ & $0.083^{\mathrm{NS}}$ \\
\hline 11 & $\begin{array}{l}\text { Annual family income from } \\
\text { livestock and poultry }\end{array}$ & $0.047^{\mathrm{NS}}$ & $0.274 * *$ & $0.306 * *$ \\
\hline 12 & $\begin{array}{c}\text { Annual family income from } \\
\text { sources other than livestock and } \\
\text { poultry }\end{array}$ & $0.286 * *$ & $0.249 *$ & $-0.073^{\mathrm{NS}}$ \\
\hline 13 & $\begin{array}{c}\text { Total annual income from all } \\
\text { sources }\end{array}$ & $0.080^{\mathrm{NS}}$ & $0.271 * *$ & $-0.018^{\mathrm{NS}}$ \\
\hline 14 & $\begin{array}{l}\text { Attitude towards improved } \\
\text { livestock farming }\end{array}$ & $0.385 * *$ & $0.211 *$ & $0.368 * *$ \\
\hline 15 & Liking of information sources & $0.363 * *$ & $0.231 *$ & $0.415 * *$ \\
\hline 16 & Entrepreneurship behaviour & $0.325 * *$ & $0.782 * *$ & $0.420 * *$ \\
\hline
\end{tabular}

NS Non-significant. *Significant at 5\% level. **Significant at $1 \%$ level. 
Table.3 Multiple regression co-efficient of empowerment of tribal women on their socioeconomic and psychological traits

\begin{tabular}{|c|c|c|c|c|c|c|}
\hline \multirow{2}{*}{$\begin{array}{l}\text { Independent } \\
\text { Variable }\end{array}$} & \multicolumn{2}{|c|}{ Deb Barma } & \multicolumn{2}{|c|}{ Jamatia } & \multicolumn{2}{|c|}{ Pooled } \\
\hline & "b" value & "t" value & "b" value & "t" value & "b" value & "tt" value \\
\hline Age (yr.) & 0.307 & 0.764 & -0.300 & -0.638 & -0.147 & -0.486 \\
\hline Family Size & 0.467 & 0.389 & -0.220 & -0.334 & -0.197 & -0.294 \\
\hline Education & 1.573 & 1.154 & -1.614 & -1.439 & 0.006 & 0.006 \\
\hline Social participation & 1.076 & 0.509 & 1.768 & 1.007 & 2.464 & 1.901 \\
\hline $\begin{array}{c}\text { Experience (yr.) in } \\
\text { livestock } \\
\text { enterprises }\end{array}$ & -0.046 & -0.126 & 0.301 & 0.659 & 0.229 & 0.815 \\
\hline Herd/flock size & -1.910 & -1.371 & -5.169 & $-3.619 * *$ & -3.176 & $-3.141 * *$ \\
\hline Land holding (acre) & 0.916 & 0.544 & -1.963 & -1.369 & 0.037 & 0.032 \\
\hline $\begin{array}{c}\text { Mass media } \\
\text { exposure }\end{array}$ & 0.684 & 0.427 & 2.845 & 1.901 & 1.218 & 1.055 \\
\hline Extension contact & 1.338 & 1.495 & 0.418 & 0.562 & 0.663 & 1.154 \\
\hline $\begin{array}{c}\text { Annual family } \\
\text { income from } \\
\text { livestock and } \\
\text { poultry }\end{array}$ & 0.000 & 0.080 & 0.000 & 1.702 & 0.000 & $2.046^{*}$ \\
\hline $\begin{array}{l}\text { Annual family } \\
\text { income from } \\
\text { sources other than } \\
\text { livestock and } \\
\text { poultry }\end{array}$ & 0.000 & -0.272 & 0.000 & 0.772 & 0.000 & 1.156 \\
\hline $\begin{array}{l}\text { Total income from } \\
\text { all the sources }\end{array}$ & 0.000 & 0.258 & 0.000 & -0.776 & 0.000 & -1.184 \\
\hline $\begin{array}{l}\text { Attitude towards } \\
\text { livestock farming }\end{array}$ & 0.991 & $2.924 * *$ & 0.135 & 0.455 & 0.797 & $3.491 * *$ \\
\hline $\begin{array}{c}\text { Liking of } \\
\text { information source }\end{array}$ & 0.899 & $1.995^{*}$ & -0.915 & -1.420 & 0.667 & 1.886 \\
\hline $\begin{array}{c}\text { Entrepreneurship } \\
\text { behaviour }\end{array}$ & 1.089 & $2.384 *$ & 4.600 & $8.642 * *$ & 2.356 & $6.656^{* *}$ \\
\hline $\begin{array}{l}\text { Participation of the } \\
\text { respondents in } \\
\text { livestock } \\
\text { enterprises }\end{array}$ & -0.385 & -1.411 & 0.642 & $2.761 * *$ & 0.181 & 1.020 \\
\hline \multirow[t]{2}{*}{$\begin{array}{l}\text { Time spent by the } \\
\text { respondents in } \\
\text { livestock } \\
\text { enterprises }\end{array}$} & 0.085 & 1.714 & 0.108 & 1.875 & 0.116 & $3.201 * *$ \\
\hline & \multicolumn{2}{|c|}{$\begin{array}{l}\mathrm{R}^{2}=0.412, \\
\text { ' } \mathrm{F} \text { 'value for } \mathrm{R}=3.630 * *\end{array}$} & \multicolumn{2}{|c|}{$\begin{array}{l}\mathrm{R}^{2}=0.730 \\
\text { ' } \mathrm{F} \text { 'value for } \mathrm{R}=14.003 * *\end{array}$} & \multicolumn{2}{|c|}{$\begin{array}{l}\mathrm{R}^{2}=0.466 \\
\text { 'F'value for } \mathrm{R}=9.968 * *\end{array}$} \\
\hline
\end{tabular}


The significant and positive relationship of social participation of the respondents with their empowerment level was the outcome of their interaction with different individuals, extension functionaries, NGOs, etc. which provided them opportunities in gathering information related to some developmental projects and programmes, knowledge about emerging technologies and encouraging success stories. Therefore, higher social participation had some positive influence over empowerment level.

In Jamatia tribe, the highly positive and significant relationship of mass media with their empowerment level might be explained by the fact that it plays an educative and informative role in the society. Therefore, the respondents could educate themselves in different aspects of life and also could gather information relating to political, social and legal issues which enlightened them and encouraged them to march forward and thereby attain higher empowerment level.

The positive and highly significant relation of extension contact in Jamatia tribe with their empowerment level implied that they could gather information and technologies from extension functionaries, could develop their skill and the utilization of such knowledge and skill earned them higher income.

Further they could also learn from the extension functionaries regarding the emerging issues of health, hygiene and environment, etc. All these together help them to achieve higher empowerment level.

Annual income from sources other than livestock showed positive and highly significant correlation with their perceived level of empowerment. It is indicative of the fact that higher the annual income from other sources better the empowerment level in economic dimension. Total annual income from all sources was found to be positive and highly significant which indicated that higher the income better the empowerment level. The reason has been clarified earlier in Deb Barma.

Attitude toward improved livestock farming showed positive and highly significant correlation with their perceived empowerment level. The explanation is same with that of Deb Barma tribe.

Liking of information sources was found to be highly significant in relation to their empowerment level. The justification for the above finding was explained in previous result in Deb Barma tribe.

Entrepreneurship behaviour exhibited highly significant relationship with perceived empowerment level indicating the fact that higher the entrepreneurship behaviour better was the empowerment level. Justification for this finding was explained earlier in Deb Barma tribe.

Similar studies were conducted by various authors who reported diverse findings. Deshmukh and Naik (2017) who revealed that the respondents' extension contact $\left(0.16165^{*}\right)$ were found positive and significant, while the annual income $\left(0.19538^{* *}\right)$ and social participation $\left(0.25067^{* *}\right)$ were found positive and highly significant relationship with process empowerment. Mandal and Sant (2017) also in their study on 100 tribal families of Anuppur District of Madhya Pradesh found that age, literacy and years of experience in animal husbandry were positively and significantly correlated with decision making pattern of tribal families in animal husbandry practices. Chauhan (2011) also in his study observed that relation between family type and their participation in animal husbandry was found to be positive and significant. 
In Table 3, the multiple regression coefficients are given.

Sixteen independent variables were first put to multiple regression analysis for both Deb Barma and Jamatia tribe to assess the probable level of contribution of the independent variable in explaining the dependent variables. The predictive power of each of multiple regressions was estimated with the help of the co-efficient of determination $\left(\mathrm{R}^{2}\right)$.

In multiple regression analysis it was observed that two variables viz., liking of information sources $\left(1.995^{*}, \mathrm{P}<0.05\right)$ and entrepreneurship behaviour $\quad\left(2.384^{*}, \quad \mathrm{P}<0.05\right) \quad$ showed significant contributing effect on empowerment level whereas attitude towards livestock farming $\left(2.924^{* *}, \mathrm{P}<0.01\right)$ showed highly significant effect on empowerment level in Deb Barma tribe. The co-efficient of determination $\left(\mathrm{R}^{2}\right)$ was found to be 0.412 indicating that $41.20 \%$ of variation in empowerment level could be explained by these variables. The F value (3.630) was found to be positive and highly significant and indicated that these three variables were good predictors of empowerment level.

Whereas in Jamatia tribe only three variables viz. herd size/flock size $(-3.619 * *, \mathrm{P}<0.01)$, entrepreneurship behaviour $\left(8.642^{* *}, \mathrm{P}<0.01\right)$ and participation of the respondents in livestock enterprises $\quad\left(2.761^{* *}, \quad \mathrm{P}<0.01\right)$ showed highly significant contributing effect on empowerment level as presented in Table 3 . The co-efficient of determination (R2) was found to be 0.730 indicating that $73.00 \%$ of variation in empowerment level could be explained by these variables. The $\mathrm{F}$ value (14.003) was found to be positive and highly significant and indicated that these three variables were good predictors of empowerment level. In pooled sample out of the seventeen variables as many as five variables viz. herd/flock size, annual family income from livestock and poultry, attitude toward improved livestock farming, entrepreneurship behaviour and time spent by the respondents in livestock enterprises exhibited significant effect on empowerment level. The co-efficient of determination $\left(\mathrm{R}^{2}\right)$ in pooled data was 0.466 which indicated that $46.60 \%$ of variation in empowerment level could be explained by these variables. The significant $F$ value (9.968) indicated that these five variables were good predictors of empowerment level.

All the remaining variables viz. age, family size, land holding, education, social participation, experience in livestock farming, annual family income from sources other than livestock and poultry, annual family income from all sources, extension contact and mass media exposure could not contribute significantly to factors influencing empowerment.

Multiple regression analysis in Table 3 revealed that out of seventeen independent variables only three variables viz., Liking of information sources $\left(1.995^{*}, \quad \mathrm{P}<0.05\right)$ and Entrepreneurship behaviour (2.384*, $\mathrm{P}<0.05)$, Attitude towards livestock farming $(2.924 * *$, $\mathrm{P}<0.01)$ displayed significant contributory effect on overall empowerment level in Deb Barma tribe. The co-efficient of determination $\left(\mathrm{R}^{2}\right)$ was found to be 0.412 indicating that 41.20 per cent of variation in empowerment level could be explained by these variables. The $\mathrm{F}$ value (3.630) was found to be positive and highly significant and indicated that these three variables were good predictors of empowerment level.

On the other hand, in Jamatia tribe only three variables viz. herd size/flock size $\left(-3.619^{* *}\right.$, $\mathrm{P}<0.01)$ Entrepreneurship behaviour $(8.642 * *, \mathrm{P}<0.01)$ and participation of women in livestock activities (2.761**, $\mathrm{P}<0.01)$ showed highly significant contributing effect 
on empowerment level. The co-efficient of determination (R2) was found to be 0.730 which indicated that 73.00 per cent of variation in empowerment level could be explained by these variables. The $\mathrm{F}$ value (14.003) was found to be positive and highly significant and indicated that these three variables were good predictors of empowerment level.

In pooled sample out of the seventeen variables as many as five variables viz. Herd/flock size, annual income from livestock, attitude toward improved livestock farming, entrepreneurship behaviour and time spent exhibited to have significant effect on empowerment level. The co-efficient of determination $\left(\mathrm{R}^{2}\right)$ in pooled data was 0.466 which indicated that 46.60 per cent of variation in empowerment level could be explained by these variables. The significant $\mathrm{F}$ value (9.968) indicated that these five variables were good predictors of empowerment level.

Finally it can be summarized that in both the tribes there was preponderance of respondents in medium category of overall empowerment through livestock enterprises. However, in relational analysis the two tribes differed to a substantial extent. In DebBarma tribe overall women empowerment showed highly significant and positive relationship with annual income from sources other than livestock, attitude towards livestock farming, liking of information source and entrepreneurial behavior. But social participation exhibited a significant relation at $5 \%$ level of probability. Out of the seventeen traits only two traits viz liking of information source and entrepreneurship behavior displayed a significant contributory effect on overall empowerment level for this tribe. The coefficient of determination was found to be 0.412 which indicated that $41.02 \%$ of variation in empowerment level could be explained by these variables. On the other hand in Jamatia tribe mass media exposure, extension contact, annual family income from livestock, total family income from all sources and entrepreneurship behavior exhibited highly significant and positive relation with overall empowerment. However, attitude towards improved livestock farming and liking of information sources showed significant relation at $5 \%$ level of probability. Three variables viz herd size, entrepreneurship behavior and participation in livestock activities showed significant contributory effect on empowerment level. The coefficient of determinant was 0.73 which indicated $73.00 \%$ of variation in empowerment could be explained by these variables.

\section{References}

Anonymous. (2012-17). Report of the working group on animal husbandry and dairying, 12th five-year plan (201217). Planning Commission, Govt. of India, New Delhi.

Chauhan, N.M. (2011). Role performance of tribal farm women in agricultural and animal husbandry in Gujarat. Karnataka J. Agric. Sci.,24 (5): (672674).

Debbarman, C. (2017). Role of indigenous pig for sustainable livelihood security of tribal farmers in North-East India. Ph. D Thesis, C.V.Sc., Assam Agricultural University, Khanapara, Guwahati, India.

Deshmukh, D. and Naik, R.M. (2017). Relationship between personal profile and empowerment of rural women through SHGs. Guj. J. Ext. Edu., 28(1).

Duguma, B., Kechero, Y.., Janssens, G.P.J. (2011). Analysis of constraints facing urban dairy farmers and gender responsibility in animal management in Jimma Town. African J. Basic \& 
Appl. Sci., 3 (6): 313-318.

Hassan, Z. (2000). Assessing the poverty and vulnerability impact of micro-credit in Bangladesh: a case study of BRAC, Washington, D.C.: World Bank.

Islam, N., Ahmed, E., Chew, J. and D'Netto, B. (2012). Determinants of empowerment of rural women in Bangladesh. World J. of Management, 4(2), 36-56. Retried from http://www.wbiaus.org/7.\%20Brian.pd $\mathrm{f}$.

Islam, S.S. (2012). Empowerment of rural women through microfinance. M. Sc. Thesis, Assam Agricultural University, Jorhat, Assam, India.

Jyothi, K.S. (1998). Empowerment pattern and empowerment of rural women. A study in Kolar district. M.Sc. Thesis, University of Agricultural Sciences, Bangalore.

Kalai, K. and Devarani, L. (2018). Gender differences in agricultural empowerment: A cross-cultural study in Tripura. Indn. Res. J. Ext. Edu.,18 (3).

Kochar, G. (2012). 'Role of dairy cooperatives in empowerment of rural women of Ludhiana district'. M. Sc. Thesis, Punjab Agricultural University, Ludhiana, India.

Mahmud, S., Shah, N.M. and Becker, S. (2012). Measurement of women's empowerment in rural Bangladesh. World Development, 40(3), 610-619. http://dx.doi.org/10.10.1016/j.worldde v. 2011.08.003.

Malik, A., Gautam and Kamaldeep. (2015). Participation of rural women in animal husbandry development programmes and decision making regarding animals in Haryana. As. J. Ani. Sci., 10(1): 6973.

Mandal, M.K. and Sant, S. (2017). Sociopersonal profile of tribal women or tribal families in relation to degree of belief and decision making pattern in animal husbandry practices. Asian $J$. Agri. Ext. Econ. Socio., 15(4):1-7.

Patel, S.J., Patel, M.D., Patel, J.H., Patel, A.S. and Gelani, R.N. (2016). Role of women gender in livestock sector: A review. J. Liv. Sci., 92-96.

Saikia, P. (2017). A Study on livelihood status of Mising women in tribal society of Assam. Indn. Res. J. Ext. Edu.,18 (1).

Talukdar, J. (2012). Status of health, empowerment and animal husbandry related to rural women. M. V. Sc. Thesis, C.V.Sc., Assam Agricultural University, Khanapara, Guwahati, India.

Torkelsson, A. and Tassew, B. (2008). Quantifying women's and men's rural resource portfolios-empirical evidence from Western Shoa in Ethiopia. The Euro. J Dev Res20: 462-81.

Yasmin, S. and Ikemoto, Y. (2015). Women's empowerment through small-scale dairy farming in selected areas of Bangladesh. As. So. Sci.,11(26).

\section{How to cite this article:}

Keshab Jamatia, M. N. Ray, Sadananda Payeng, Leema Bora, Monosri Johari and Deepjyoti Roy. 2021. Correlates of Tribal Women's Empowerment in Tripura. Int.J.Curr.Microbiol.App.Sci. 10(02): 2154-2164. doi: https://doi.org/10.20546/ijcmas.2021.1002.256 